\title{
The Genetic Non-Discrimination Act: critical for promoting health and science in Canada
}

\author{
Yvonne Bombard PhD, Bev Heim-Myers BComm
}

- Cite as: CMAJ 2018 May 14;190:E579-80. doi: 10.1503/cmaj.180298

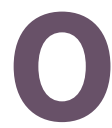

n May 4, 2017, Bill S201, an act to prohibit and prevent genetic discrimination, received royal assent and became federal law. The Genetic Non-Discrimination Act (GNA) is critical for promoting the health of Canadians and ensuring Canada remains on the cutting edge of genomics research. The GNA protects genetic test information from any individual or service provider - be it an insurer, employer, school, landlord or adoption agency - entering into a contract with a person. The Government of Quebec, however, is challenging the constitutionality of the act. Although the act passed into law only last May, it has already had a positive impact. It is therefore imperative that it remains intact for all Canadians.

Advances in genomic science are providing unprecedented opportunities to better facilitate the prevention, treatment and early diagnosis of many diseases. Indeed, a recent CMAJ article from the Personal Genome Project Canada, which reports on the whole genome sequences and linked health data of 56 volunteers, illustrates the power of the technology to identify medically relevant information, such as pharmacogenetic variants, and the promise of the technology to influence health care. ${ }^{1}$

However, people's fear of having their genetic information used against them by third parties, such as insurers or employers, remains a fundamental barrier to accessing genetic testing. Studies have shown that patients and providers are deterred from the use of genetic tests because of fears that an unfavourable result will lead to difficulties with insurance. ${ }^{2,3}$ Likewise, some patients feel they must hide their family histories from their health care providers to avoid having their family history contained in their medical records, preempting the possibility of genetic discrimination. ${ }^{4}$ Such fear creates barriers to accessing important information that can end costly, burdensome diagnostic odysseys, guide medical management and improve a patient's quality of life.

Fear of genetic discrimination also prevents patients from participating in research, which can stifle Canada's scientific advances in genomic medicine. Concern about insurance discrimination, in particular, has already been shown to deter people from participating in genetic studies. ${ }^{5,6}$

Prohibitions found in sections 3-5 of the GNA make it a criminal offence for a service provider or anyone entering into a contract with a person to require or compel that person to take or disclose

\section{KEY POINTS}

- The Genetic Non-Discrimination Act (GNA) makes it a criminal offence for a service provider or anyone entering into a contract with a person to require or compel that person to take, or disclose the results of, a genetic test.

- The GNA is critical for promoting the health of Canadians and ensuring Canada remains on the cutting edge of genomics research.

- The Government of Quebec is challenging the constitutionality of the act.

- Although the act passed into law only last May, it has already had a positive impact; it is therefore imperative that it remains intact for all Canadians.

the results of a genetic test. The prohibitions also make it a criminal offence to collect, use or disclose a person's genetic test results without explicit written consent. The act sets out maximum criminal penalties of a fine up to $\$ 1$ million or possible imprisonment up to five years. However, there are exceptions. Sections 3-5 of the GNA do not apply to a physician, a pharmacist or any other health care practitioner with respect to an individual to whom they are providing health care services. Sections 3-5 also do not apply to a person who is conducting medical, pharmaceutical or scientific research with respect to an individual participating in the research.

The GNA is a critical law affording comprehensive protection prohibiting genetic discrimination by any individual or sector. Unfortunately, the constitutionality of this law is being challenged in Quebec. The Government of Quebec referred the GNA to the Court of Appeal of Quebec on the grounds that the legislation is not constitutional. The GNA addresses the harmful behaviour of genetic discrimination; however, parties supporting the appeal argue that the prohibition is targeted at the insurance industry, which is regulated at the provincial (not federal) level in Canada. If the appeal is granted, it will be referred to the Supreme Court of Canada.

If the GNA is successfully overturned in Quebec, and subsequently by the Supreme Court of Canada, this will enable genetic discrimination, which is a bigger problem than many Canadians realize. Recognizing the limited policy protections and empirical evidence in Canada, Bombard and colleagues conducted a national study on the nature and extent of genetic 
discrimination. ${ }^{7}$ The survey of individuals with a family history of Huntington disease found that $86 \%$ feared genetic discrimination; $40 \%$ actually experienced it (mainly by providers of life and longterm disability insurance), and those with positive genetic tests reported more experiences of genetic discrimination. ${ }^{7}$

Through in-depth interviews, Bombard and colleagues documented cases of entrepreneurs and homeowners unable to get life insurance to back up their loans (a standard requirement for large loans and mortgages in Canada) because of the results of genetic testing. ${ }^{8}$ There were also cases of employees passed over for promotions and families turned down for adoptions based on genetic features. ${ }^{8}$ These experiences are not unique to Huntington disease or to Canada; similar incidents have been reported in cancer and pediatric settings across other countries. ${ }^{9,10}$ Many of those countries, however, had policies to protect citizens against genetic discrimination. Canada joined their ranks only last year.

For now, the genetic test information of all people living in Canada, no matter where they live, is protected by law. And it is important that the GNA remains intact. It has already begun to allay patients' fears, encourage participation in genomics research, and empower patients and their families to take genetic tests and preventive measures to reduce risks of future diseases. ${ }^{11}$ All Canadians deserve access to the best possible health care without fear of genetic discrimination.

\section{References}

1. Reuter MS, Walker S, Thiruvahindrapuram B, et al. The Personal Genome Project Canada: findings from whole genome sequences of the inaugural 56 participants. CMAJ 2018;190:E126-36.

2. Godard B, Pratte A, Dumont M, et al. Factors associated with an individual's decision to withdraw from genetic testing for breast and ovarian cancer susceptibility: implications for counseling. Genet Test 2007;11:45-54.

3. Lowstuter KJ, Sand S, Blazer KR, et al. Influence of genetic discrimination perceptions and knowledge on cancer genetics referral practice among clinicians. Genet Med 2008;10:691-8.

4. Bombard Y, Penziner E, Decolongon J, et al. Managing genetic discrimination: strategies used by individuals found to have the Huntington disease mutation. Clin Genet 2007;71:220-31.

5. Hadley DW, Jenkins J, Dimond E, et al. Genetic counseling and testing in families with hereditary nonpolyposis colorectal cancer. Arch Intern Med 2003; 163:573-82.

6. Hall MA, McEwen JE, Barton JC, et al. Concerns in a primary care population about genetic discrimination by insurers. Genet Med 2005;7:311-6.

7. Bombard Y, Veenstra G, Friedman JM, et al.; Canadian Respond-HD Collaborative Research Group. Perceptions of genetic discrimination among people at risk for Huntington's disease: a cross sectional survey. BMJ 2009;338:b2175.

8. Bombard Y, Penziner E, Suchowersky O, et al. Engagement with genetic discrimination: concerns and experiences in the context of Huntington disease. Eur J Hum Genet 2008;16:279-89.

9. Otlowski M, Taylor S, Bombard Y. Genetic discrimination: international perspectives. Annu Rev Genomics Hum Genet 2012;13:433-54.

10. Joly Y, Ngueng Feze I, Simard J. Genetic discrimination and life insurance: a systematic review of the evidence. BMC Med 2013;11:25.

11. Gibson V. Genetic testing back on radar for parents. Toronto Star 2017 Aug. 9. Available: www.thestar.com/news/gta/2017/08/09/genetic-testing-back-on -radar-for-parents.html (accessed 2018 Mar. 6).
Competing interests: Yvonne Bombard reports grants from the Canadian Institutes of Health Research, which supported the conduct of the studies reported herein. Yvonne Bombard and Bev Heim-Myers served as expert witnesses to provide both oral and written testimony for the Parliament of Canada's Standing Senate Committee on Human Rights on Bill S-201. Bev Heim-Myers is chair of the Canadian Coalition for Genetic Fairness, which has a membership of more than 18 notfor-profit charitable organizations.

This article was solicited and has not been peer reviewed.

Affiliations: Institute of Health Policy, Management and Evaluation, University of Toronto (Bombard); Li Ka Shing Knowledge Institute, St. Michael's Hospital (Bombard), Toronto, Ont.; Huntington Society of Canada
(Heim-Myers); Canadian Coalition for Genetic Fairness (Heim-Myers), Kitchener, Ont.

Contributors: Both authors conceived, drafted and revised the manuscript, gave final approval of the version to be published and agreed to be accountable for all aspects of the work.

Correspondence to: Yvonne Bombard, yvonne.bombard@utoronto.ca 